Jurnal BASTRA (Bahasa dan Sastra) : http://ojs.uho.ac.id/index.php/BASTRA

\title{
PENGARUH MODEL PEMBELAJARAN BERBASIS MASALAH TERHADAP KEMAMPUAN MENULIS TEKS PERSUASI SISWA KELAS VIII SMP NEGERI 11 KONAWE SELATAN
}

\section{OLEH}

\author{
Elisa Megawati', Zalili Sailan' ${ }^{2}$, dan Sahlan ${ }^{3}$ \\ ${ }^{1}$ Alumni Jurusan Pend. Bahasa dan Sastra Indonesia, ${ }^{2,3}$ Dosen Jurusan \\ Pendidikan Bahasa dan Sastra Indonesia, Fakultas Keguruan dan Ilmu \\ Pendidikan Universitas Halu Oleo
}

\begin{abstract}
ABSTRAK
Penelitian ini bertujuan untuk mengetahui pengaruh model pembelajaran berbasis masalahterhadap kemampuan menulis teks persuasi siswa kelas VIII SMP Negeri 11 Konawe Selatan terfokus pada kelas VIII-A. Desain penelitian One Group Pretest-Postest dan metode yang digunakan dalam penelitian ini adalah Preeksperimen. Berdasarkan hasil penelitian dalam menulis teks persuasi siswa kelas VIII-A SMP Negeri 11 Konawe Selatan sebelum pembelajaran menggunakan model pembelajaran berbasis masalahpada materi teks persuasi tergolong tinggi, cukup, dan rendah dimana 4 siswa atau 13,79\% siswa yang memperoleh nilai 75, serta 23 atau $79,31 \%$ siswa memperoleh nilai antara 43 sampai 68 , dan 2 siswa atau $6,89 \%$ yang memperoleh nilai 25 . Kemudian setelah menggunakan model pembelajaran berbasis masalahmeningkat dengansangat baik, karena dimana dari 29 siswa mendapatkan pengaruh dan memperoleh nilai sangat baik dibandingkan sebelum menggunakan model pembelajaran berbasis masalahdiantaranya 3 atau 10,34\% siswa yang memperoleh nilai 62 sampai 68, serta 19 atau 65,51\% siswa memperoleh nilai antara 75 sampai 87 , dan 7 atau $24,13 \%$ memperoleh nilai antara 93 sampai 100. Pembelajaran menggunakan model pembelajaran berbasis masalahmemberikan pengaruh positif yang signifikan terhadap kemampuan menulis teks persuasi siswa kelas VIII-A SMP Negeri 11 Konawe Selatan. Hal ini berdasarkan hasil analisis inferensial menggunakan SPSS version 16.0 dengan nilai $t_{\text {hitung }}=8,814$ dan $p=0,000$ $<\alpha=0,05$ artinya secara keseluruhan siswa telah mampu dalam menulis teks persuasi.
\end{abstract}

Kata Kunci: pengaruh, model pembelajaran masalah, menulis teks, persuasi 
PENDAHULUAN

\subsection{Latar Belakang}

Pendidikan menurut UndangundangNo.20Tahun 2003 tentang sistem pendidikan Nasional Bab 1 Pasal 1 Pendidikan adalah usaha sadar dan terencana untuk mewujudkan suasana belajar dan proses pembelajaran agar peserta didik secara aktif dapat mengembangkan potensi dirinya, masyarakat, bangsa dan negara (Syah, 2014:1).Mengingat pentingnya pendidikan maka siswa wajib mengikuti pembelajaran disekolah khusunya pelajaran Bahasa Indonesia. Pembelajaran Bahasa Indonesia dalam kurikulum 2013 diorientasikan pada pembelajaran berbasis teks.

Keterampilan berbahasa memiliki empat komponen, yaitu keterampilan menyimak (listening skils), keterampilan berbicara (speaking skils), keterampilan membaca (reading skils), dan keterampilan menulis (writing skils). Dari keempat keterampilan berbahasa tersebut, keterampilan menulislah yang paling penting hal tersebut dikarenakan menulis bukanlah suatu bakat yang dibawa dari lahir, melainkan kemampuan yang harus dipelajari sejak dini dimana saat pertama kali mengenal huruf dan kata-kata baru.

Menurut Wiyanto (dalam Mariani, 2010:1) menciptakan iklim budaya menulis akan mendorong seseorang menjadi aktif, lebih kreatif, dan lebih cerdas. Tetapi, realitanya masih banyak siswa yang belum mampu menulis. dalam hal ini, seharusnya pembelajaran peserta didik hendaknya dibimbing dengan hal yang nyata. tujuannya agar siswa lebih mudah memahami materi, dan dapat untuk menambah daya ingat siswa, juga membuat siswa menjadi lebih kreatif. Untuk itu, dalam pembelajaran keterampilan menulis sangatlah penting bagi siswa khususnya berlatih menulis teks persuasi.

Teks persuasi adalah ragam wacana yang ditunjukan untuk mempengaruhi sikap dan pendapat pembaca mengenai sesuatu hal yang disampaikan penulisnya
(Yunus, 2006:13).Berdasarkan hasil observasi yang dilakukan peneliti memperoleh informasi dari guru Bahasa Indonesia di SMP Negeri 11 Konawe Selatan kelas VIII khususnya kelas VIII-A, permasalahan yang terdapat pada siswa yaitu banyak siswa yang kurang berminat dalam menulis teks persuasi, siswa mengalami kesulitan penulisan struktur teks persuasi, siswa mengalami kesulitan dalam mengeluarkan ide gagasan ke dalam bentuk tulisan, dan perasaan takut salah atau berbeda dengan teman lainnya juga menghambat siswa dalam menulis teks persuasi.

Menurut Bern dan Erickson (dalam Komalasari, 2015: 59) model pembelajaran berbasis masalah merupakan strategi pembelajaran yang melibatkan siswa dalam memecahkan masalah dengan mengintegrasikan berbagai konsep dan keterampilan dari berbagai disiplin ilmu. Pada pembelajaran teks persuasi ini dibandingkan dengan menggunakan model pembelajaran berbasis ceramah tradisional, pembelajaran berbasis masalah memiliki banyak manfaat yang didapat saat belajar yaitu dapat meningkatkan motivasi belajar, membuat pembelajaran yang relevan dengan dunia nyata, dapat mendorong pembelajaran belajar, juga dapat memberikan kesempatan bagi siswa untuk mengaplikasikan pengetahuan yang dimiliki kedalam dunia nyata.

Dengan demikian, model pembelajaran berbasis masalah dapat ini dapat mendorong siswa berfikir secara alamiah untuk mencari solusi dari permasalahan dunia nyata dan menulis teks persuasi akan mudah dilakukan, jika masalah tersebut ditulis menjadi teks persuasi. Hal ini dapat menantang siswa untuk terus belajar dan menambah minat menulis. Selain itu, kurikulum 2013 pembelajaran berbasis teks khususnye teks persuasi terdapat di kelas VIII dan model pembelajaran berbasis masalah belum diterapkan di sekolah SMP Negeri 11 Konawe Selatan. 
Selain itu, untuk menulis teks persuasi dengan menggunakan model pembelajaran berbasis masalah sudah terbukti berhasil atau dapat mempengaruhi kemampuan siswa dalam menulis terks persuasi pada siswa SMP Negeri di daerah Kendari. Hal ini membuat peneliti ingin mencoba apakah dengan menggunakan model pembelajaran berbasis masalah pada siswa SMP Negeri 11 Konawe Selatan juga dapat mempengaruhi kemampuan siswa dalam menulis.

Berdasarkan uraian di atas, maka peneliti tertarik mengambil judul "Pengaruh Model Pembelajaran Berbasis Masalah Terhadap Kemampuan Menulis Teks Persuasi Siswa Kelas VIII SMP Negeri 11 Konawe Selatan".

\subsection{Rumusan Masalah}

Berdasarkan latar belakang di atas, maka rumuskan masalah dalam penelitian ini adalah apakah pengaruh model pembelajaran berbasis masalah terhadap kemampuan menulis teks persuasi siswa kelas VIII SMP Negeri 11 Konawe Selatan?

\subsection{Tujuan Penelitian}

Berdasarkan rumusan masalah tersebut, tujuan yang ingin dicapai dalam penelitian ini adalah untuk mengetahui apakah pengaruh model pembelajaran berbasis masalah terhadap kemampuan menulis teks persuasi siswa kelas VIII SMP Negeri 11 Konawe Selatan.

\subsection{Manfaat Penelitian}

Manfaat yang diharapkan dari penelitian ini adalah sebagai berikut.

1. Bagi guru, dapat memberikan alternatif model pembelajaran yang efektif dalam meningkatkan aktivitas dan penguasaan materi siswa.

2. Bagi siswa, dapat memberikan pengalaman belajar yang aktif dan menyenangkan, serta dapat meningkatkan aktivitas dan penguasaan materi siswa.
3. Bagi sekolah, dapat memberikan sumbangan pikiran untuk meningkatkan mutu pembelajaran Bahasa Indonesia di sekolah.

\subsection{Batasan Operasional}

1. Menulis merupakan sebuah kegiatan menuangkan pikiran, gagasan, dan perasaan seseorang yang diungkapkan dalam bahasa tulis.

2. Teks Persuasi adalah ragam wacana yang ditunjukan untuk mempengaruhi sikap dan pendapat pembaca mengenai sesuatu hal yang disampaikan penulisnya.

3. Pembelajaran Berbasis Masalah adalah strategi pembe;ajaran yang melibatkan siswa dalam memecahkan masalah dengan mengintegrasikan berbagai konsep dan keterampilan dari berbagai disiplin ilmu.

\section{KAJIAN PUSTAKA}

\subsection{Model Pembelajaran}

\subsubsection{Pengertian Model Pembelajaran}

Menurut Joyce \& Weil (1980) model pembelajaran adalah suatu rencana atau pola yang dapat digunakan untuk membentuk kurikulum (rencana pembelajaran jangka panjang), merancang bahan-bahan pembelajaran, dan membimbing pembelajaran di kelas atau yang lain. Model pembelajaran dapat dijadikan pola pilihan, artinya para guru boleh memilih model pembelajaran yang sesuai dan efisien untuk mencapai tujuan pendidikannya (Rusman, 201:139).

\subsubsection{Ciri-ciri Model Pembelajaran}

Menurut Rusman (2010:142), model pembelajaran memiliki ciri-ciri yaitu (1) berdasarkan teori pendidikan dan teori belajar dari para ahli tertentu, (2) mempunyai misi atau tujuan pendidikan tertentu, (3) dapat dijadikan pedoman untuk perbaikan kegiatan belajar mengajar di kelas, (4) memiliki bagian-bagian model yang dinamakan langkah-langkah dan adanya prinsip-prinsip reaksi, (5) memiliki dampak sebagai akibat terapan model 
pembelajaran, (6) membuat persiapan mengajar (desain intruksional) dengan pedoman model pembelajaran yang dipilihnya.

\subsection{Model Pembelajaran Berbasis Masalah}

Menurut Bern dan Erickson (dalam Komalasari, 2015 : 59) pembelajaran berbasis masalah merupakan strategi pembelajaran yang melibatkan siswa dalam memecahkan masalah dengan mengintegrasikan berbagai konsep dan keterampilan dari berbagai disiplin ilmu.

Pada pembelajaran ini membantu siswa untuk memproses informasi yang sudah jadi dalam benaknya dan menyusun pengetahuan mereka sendiri tentang dunia sosial dan sekitarnya. Pembelajarn ini cocok untuk mengembangkan pengetahuan dasar maupun kompleks. Hakikat maslaah dalam pembelajaran berbasis masalah adalah kesenjangan antara situasi nyata dan kondisi yang diharapkan, atau antara kenyataan yang terjadi dengan apa yang diharapkan.

\subsubsection{Langkah-langkah Model Pembelajaran Berbasis Masalah}

Menurut Nur (dalam Ana, 2011:25) pembelajaran berbasis masalah dibagi atas lima langkah sebgai berikut.

1) Orientasi siswa pada masalah yaitu guru menjelaskan tujuan pembelajaran.

2) Mengorganisasi siswa untuk belajar yaitu guru membantu siswa untuk mengidentifikasikan dan mengorganisasikan tugas belajar.

3) individual maupun kelompok yaitu guru mendorong siswa untuk mengumpulkan informasi yang sesuai.

4) Mengembangkan dan menyajikan hasil karya yaitu guru membantu siswa dalam merencanakan dan menyiapkan karya yang sesuai dengan laporan.

5) Menganalisis dan mengevaluasi proses pemecahan masalah yaitu guru membantu siswa untuk melakukan refleksi atau evaluasi pembelajaran.

\subsubsection{Karakteristik}

Pembelajaran

Berbasis Masalah

Menurut Arends (dalam Ana, 2011:23), berbagai pengembangan pengajaran berbasis masalah telah memberikan model pembelajaran itu memiliki karakteristik sebagai berikut.

1) Pengajuan pertanyaan atau masalah.Pembelajaran berbasis masalah mengorganisasikan pengajaran disekitar pertanyaan dan masalah yang dua-duanya secara sosial penting dan secara pribadi bermakna untuk siswa.

2) Berfokus pada keterkaitan antar disiplin. Meskipun pembelajaran berbasis maslaah mungkin berpusat pada mata pelajaran tertentu (IPA, matematika, ilmu-ilmu sosial), masalah yang akan diselidiki telah dipilih benar-benar nyata agar dalam pemecahannya siswa mampu meninjau masalah itu dari banyak pelajaran.

3) Penyelidikan autentik. Pembelajaran berbasis masalah mengharuskan siswa melakukan penyelidikan autentik untuk mencari penyelesaian nyata terhadap masalah nyata.

4) Menghasilkan produk dan memamerkannya. Pembelajaran berbasis masalah menuntut siswa untuk menghasilkan produk tertentu dalam bentuk karya nyata dan peragaan yang menjelaskan atau mewakili bentuk penyelesaian masalah yang mereka temukan.

5) Kolaborasi. Pembelajaran berbasis maslaah dicirikan oleh siswa yang bekerja sama atau dengan yang lainnya secara berpasangan atau kelompok. 


\subsubsection{Kelebihan dan Kelemahan Model Pembelajaran Berbasis Masalah}

a. Kelebihan Pembelajaran Berbasis Masalah

1. Pembelajaran berbasis masalah merupakan teknik yang cukup bagus untuk memahami pelajaran.

2. Pembelajaran berbasis masalah dapat menantang kemampuan siswa serta memberikan keuasan untuk menemukan pengetahuan baru bagi siswa.

3. Pembelajaran berbasis masalah dapat meningkatkan aktifitas pembelajaran.

4. Pembelajaran berbasis masalah dapat memberikan kesempatan kepada siswa untuk mengaplikasikan pengetahuan yang mereka miliki dalam dunia nyata.

5. Pembelajaran berbasis masalah dapat mengembangkan minat siswa untuk belajar secara terus menerus.

\section{b. Kelemahan Pembelajaran Berbasis Masalah}

1. Siswa tidak mempunyai minat atau tidak mempunyai kepercayaan bahwa masalah yang dipelajari sulit untuk dipecahkan, maka mereka akan merasa ragu untuk mencoba.

2. Keberhasilan model pembelajaran berbasis masalah membutuhkan cukup waktu untuk persiapan.

3. Tanpa pemahaman mengapa mereka berusaha untuk memecahkan masalah yang sedang dipelajari, maka mereka tidak akan belajar apa yang ingin mereka pelajari.

\subsection{Hakikat Menulis}

Menurut Tarigan (2013:3), menulis merupakan suatu keterampilan berbahasa yang dipergunakan untuk berkomunikasi secara tidak langsung, tidak secara tatap muka dengan orang lain. Dalam kegiatan menulis ini, penulis harus terampil memanfaatkan grafolegi, struktur bahasa, dan kosa kata. Keterampilan menulis ini tidak akan datang secara otomatis, tetapi harus melalui latihan dan praktik yang banyak dan teratur.

\subsubsection{Tujuan Menulis}

Menurut Rosidi (2009:4) secara umum, pada kegiatan menulis terdapat beberapa garis utama yang mendasari tujuan seseorang dalam menulis diantaranya sebagai berikut.

a. Memberitahukan atau menjelaskan sesuatu biasa disebut dengan karangan eksposisi.

b. Meyakinkan atau mendesak pembaca bahwa apa yang disampaikan penulis benar sehingga penulis berharap pembaca mengikuti pendapat penulis.

c. Menceritakan sesuatu untuk menceritakan suatu kejadian kepada pembaca.

d. Mempengaruhi pembaca atau membujuk pembaca agar mengikuti kehendak penulis dengan menampilkan bukti-bukti.

e. Menggambarkan sesuatu agar pembaca seolah-olah ikut merasa, melihat, meraba, dan menikmati objek lukisan penulis.

\subsubsection{Fungsi Menulis}

Menurut Bernard Percy (dalam Soebachman, 2016:19) secara rinci mengemukakan bahwa fungsi menulis adalah:

a) Menulis sebagai sarana untuk mengungkapkan diri seperti kegelisahan, keinginan untuk meluapkan amarah.

b) Menulis sebagai sarana pemahaman, artinya dengan menulis seseorang bisa mengikat kuat suatu ilmu pengetahuan ke dalam otaknya.

c) Menulis dapat membantu mengembangkan kepuasan pribadi.

d) Menulis dapat meningkatkan kesadaran dan penyerapan terhadap lingkungan.

e) Menulis dapat meningkatkan keterlibatan secara bersemangat. 


\subsubsection{Ciri-ciri Tulisan yang Baik}

Menurut Rosidi (2009:8) ciri-ciri tulisan yang baik adalah sebagai berikut.

a. Tulisan merupakan hasil rakitan dari berbagai bahan atau pengetahuan yang dimiliki oleh penulis.

b. Mencerminkan kemampuan menulis untuk menulis dengan jelas dan tidak samar-samar.

c. Mencerminkan kemampuan menulis untuk menulis secara meyakinkan, menarik minat pembaca terhadap pokok pembicaraan.

d. Mencerminkan kemampuan penulis untuk mengkritisi masalah pada tulisannya yang pertama serta memperbaikinya.

\subsection{Teks Persuasi}

\subsubsection{Hakikat Persuasi}

Menurut Haliday dan Ruqaiyah (dalam Mahsun, 2014:1) teks merupakan jalan menuju pemahaman tentang bahasa, yakni yang berfungsi atau bahasa yang sedang melaksanakan tugas tertentu dalam konteks situasi. Sedangkan persuasi adalah ragam wacana yang ditunjukan untuk mempengaruhi sikap dan pendapat pembaca mengenai sesuatu hal yang disampaikan penulisnya (Yunus, 2006:13).

\subsubsection{Struktur Teks Persuasi}

Menurut Kosasih (2017:186) teks persuasi struktur dalam penulisan yaitu sebagai berikut.

a. Pengenalan isu, yakni berupa pengantar atau penyampaian tentang masalah yang menjadi dasar tulisan atau pembicaraannya itu.

b. Rangkaian argumen, yakni berupa sejumlah pendapat penulis/pembicara terkait dengan isu yang dikemukakan pada bagian sebelumnya.

c. Pernyataan ajakan, yakni sebagai inti dari teks persuasi yang di dalamnya dinyatakan dorongan kepada pembaca/pendengaranya untuk melakukan sesuatu. d. Penegasan kembali atas pernyataanpernyataan sebelumnya.

\subsubsection{Jenis-jenis Persuasi}

Menurut Finoza (1993:209) jenisjenis persuasi dapat digolongkan menjadi empat macam yaitu:

1) Persuasi Politik, dipakai dalam bidang politik oleh orang-orang yang berkecinambungan dalam bidang politik.

2) Persuasi Pendidikan, dipakai oleh orang-orang untuk mencapai tujuan pendidikan.

3) PersuasiAdvertensi/iklan, dimanfaatkan terutama dalam dunia usaha untuk pemperkenalkan suatu barang atau bentuk jasa tertentu.

4) Persuasi Propaganda, menyampaikan informasi yang sering dipakai dalam kegiatan kampanye.

\subsubsection{Kaidah Kebahasaan Teks Persuasi}

Menurut Kosasih (2017:188) kaidah kebahasaan berfungsi sebagai penanda utama teks persuasi yaitu terdapat pernyataan-pernyataan yang mengandung ajakan, dorongan, bujukan, dan sebagai berikut.

1) Menyajikan sejumlah fakta dan pendapat.

2) Menggunakan pernyataan-pernyataan bujukan.

3) Menggunakan kata-kata teknis atau peristilahan yang berekenaan dengan topik yang dibahas.

4) Menggunakan kata-kata penghubung yang argumentatif.

5) Menggunakan kata ganti kita.

\subsubsection{Langkah-langkah PenyusunanTeks Persuasi}

Menurut Kosasih (2017:196) langkah-langkah penyusunan teks persuasi yaitu sebagai berikut.

1) Tentukan tema atau ujukan utamanya.

2) Susunan perincian, yaitu pengenalan isu, rangkaian pendapat, ajakanajakan, dan penegasan kembali. 
3) Pengumpulan bahan, yakni pendapat, dan fakta.

4) Pengembangan teks, yakni memperhatikan struktur dan kaidah kebahasaan.

\subsection{Hipotesis Penelitian}

Hipotesis statistik yang diajukan dalam penelitian ini adalah:

1. $\mathrm{H}_{0}$ : Tidak ada pengaruh yang signifikasi penggunaan model pembelajaran berbasis masalah terhadap kemampuan menulis teks persuasi siswa.

2. $\mathrm{H}_{1}$ : Ada pengaruh yang signifikan penggunaan model pembelajaran berbasis masalah terhadap kemampuan menulis teks persuasi siswa.

\section{METODE PENELITIAN}

\section{a. Metode dan Jenis Penelitian}

Metode yang digunakan dalam penelitian ini adalah kuantitatif dan jenis penelitiannya adalah Pre-eksperimen, karena penelitian ini tanpa menggunakan kelompok kontrol dan desain ini terdapat pretest sebelum diberikan perlakuan dan posttest setelah dialkukan perlakuan.

\subsection{Variabel dan Desain Penelitian 3.2.1 Variabel Penelitian}

Penelitian ini mempunyai dua variabel, yaitu:

a. Variabel bebas yaitu perlakuan berupa pembelajaran dengan menggunakan model pembelajaran berbasis masalah.

b. Variabel terikat yaitu kemampuan menulis teks persuasi siswa yang diajar dengan menggunakan model pembelajaran berbasis masalah.

\subsubsection{Desain Penelitian}

Desain eksperimen yang digunakan dalam penelitian ini adalah pre-eksperimen yaitu menggunakan One-Group Pretest-
Posttest Design. Pada desain ini pengukuran dilakukan sebanyak dua kali, pengukuran pertama dilakukan didepan (pre-test) sebelum adanya perlakuan (treatment) dan pengukuran yang kedua (posttest) dilakukan setelah diberikan perlakuan.

\subsection{Populasi dan Sampel Penelitian}

\subsubsection{Populasi}

'Populasi dalam penelitian ini adalah seluruh peserta didik kelas VIII SMP Negeri 11 Konawe Selatan yang terdaftar pada tahun ajaran 2018/2019 yang tersebar dalam empat kelas (VIII-A, VIII-B, VIIIC, dan VIII-D).

Tabel 1 Jumlah Populasi Penelitian

\begin{tabular}{|c|c|c|}
\hline No & Kelas & Jumlah \\
\hline 1. & A & 29 orang \\
\hline 2. & B & 25 orang \\
\hline 3. & C & 26 orang \\
\hline 4. & D & 24 orang \\
\hline \multicolumn{2}{|c|}{ Jumlah } & 104 orang \\
\hline
\end{tabular}

(Sumber: SMP Negeri 11 Konawe Selatan)

\subsubsection{Sampel}

Penentuan sampel dalam penelitian ini dilakukan dengan menggunakan teknik purposive sampling atau sampel bertujuan dengan pertimbangan-pertimbangan tertentu. Sampel yang digunakan yaitu kelas VIII-A berjumlah 29 siswa sebagai perwakilan kelas VIII SMP Negeri 11 Konawe Selatan.

\subsection{Prosedur Penelitian}

Prosedur penelitian ini terdiri dari tahap perencanaan, tahap pelaksanaan, tahap akhir penelitian.

\section{Tahap Perencanaan Penelitian}

a. Mengadakan observasi ke sekolah tempat diadakannya penelitian untuk mendapatkan informasi tentang keadaan kelas yang akan diteliti.

b. Wawancara tidak terstruktur dengan guru SMP Negeri 11 Konawe Selatan untuk melihat bagaimana keadaan sampel sebelum diteliti.

161 | Jurnal BASTRA (Bahasa dan Sastra), Vol. 4 No.1, Edisi Januari 2019/e-ISSN: 2503-3875/ http://ojs.uho.ac.id/index.php/BASTRA 
c. Meminta silabus sekolah dan membuat rencana pelaksanaan pembelajaran (RPP).

d. Merancang dan membuat instrumen penelitian.

e. Menguji coba soal tes.

f. Menyiapkan materi yang akan disampaikan dalam proses belajar mengajar.

2. Tahap Penelitian

a. Melaksanakan pretest pada kelas VIIIA.

b. Melaksanakan proses pembelajaran dengan menggunakan model pembelajaran berbasis masalah.

c. Melaksanakan posttest pada kelas VIII-A.

\section{Tahap Akhir Penelitian}

a. Mengolah data hasil penelitian.

b. Melakukan analisis terhadap seluruh hasil data penelitian yang diperoleh.

c. Menyimpulkan hasil analisis data.

d. Menyusun laporan penelitian.

\subsection{Instrumen Penelitian}

Instrumen yang digunakan sebagai alat untuk mengumpulkan data dalam penelitian ini yaitu instrumen berupa tes dan yang digunakan dalam bentuk tes essay. Tujuan dari penyususnan soal tes menulis teks persuasi adalah untuk mengukur kemampuan menulis teks persuasi siswa setelah proses pembelajaran.

\subsubsection{Uji Validitas Instrumen}

Validitas instrumen yang hendak diukur adalah validitas empiris berdasarkan data hasil uji coba. Pengujian validitas dilakukan dengan SPSS menggunakan teknik korelasi product moment antara skor tiap butir soal dengan skor total. Instrumen dikatakan valid jika nilai $r_{\text {hit }}>r_{\text {tab }}=$ valid, jika $r_{\text {hit }}<r_{\text {tab }}=$ tidak valid. Nilai $r_{\text {tab }}$ dari signifikansi $=0,05$ untuk uji dua arah sebanyak 12 responden yang dikurangi $2 \mathrm{df}=(\mathrm{n}-2)$ menjadi 10 maka diperoleh nilai $r_{\text {tab }}$ sebesar 0,5760 dan berdasarkan analisis uji validitas soal pretest dan posttest di katakan valid.

Tabel Hasil Analisi Pre-test

\begin{tabular}{|c|c|c|}
\hline $\begin{array}{c}\text { Nomor } \\
\text { Soal }\end{array}$ & $\begin{array}{c}\text { Indeks } \\
\text { Validitas }\end{array}$ & Keterangan \\
\hline 1 & 0,814 & Valid \\
\hline 2 & 0,819 & Valid \\
\hline 3 & 0,792 & Valid \\
\hline 4 & 0,733 & Valid \\
\hline
\end{tabular}

Tabel Hasil Analisi Post-test

\begin{tabular}{|c|c|c|}
\hline $\begin{array}{c}\text { Nomor } \\
\text { Soal }\end{array}$ & $\begin{array}{c}\text { Indeks } \\
\text { Validitas }\end{array}$ & Keterangan \\
\hline 1 & 0,664 & Valid \\
\hline 2 & 0,854 & Valid \\
\hline 3 & 0,796 & Valid \\
\hline 4 & 0,731 & Valid \\
\hline
\end{tabular}

Berdasarkan hasil uji validitas pada tabel 2 dan 3, enyatakan semua soal dikatkan valid dalam hal ini dapat digunakan untuk tes kemampuan siswa.

\subsubsection{Uji Reliabilitas}

Reliabilitas menunjuk pada satu pengertian bahwa sesuatu instrumen cukup dapat dipercaya untuk digunakan sebagai alat pengumpulan data karena instrumen tersebut sudah baik. Untuk mengukur reliabilitas dalam penelitian menggunakan bantuan SPSS. Metode yang digunakan untuk mengukur reliabilitas kuesioner adalah metode cronbach's alpha. Kuesioner reliabel jika nilai cronbach's alpha $\geq \mathrm{r}$ tabel 0,6 atau 0,7.

Tabel 4 Hasil Analisi Reliabilitas Pre-test

\begin{tabular}{|c|c|}
\hline $\begin{array}{c}\text { Koefisien } \\
\text { Reliabilitas }\end{array}$ & $\begin{array}{c}\text { Interprestasi } \\
\text { Korelasi }\end{array}$ \\
\hline 0,775 & Tinggi \\
\hline
\end{tabular}

Tabel 5 Hasil Analisi Reliabilitas Post-test

\begin{tabular}{|c|c|}
\hline $\begin{array}{c}\text { Koefisien } \\
\text { Reliabilitas }\end{array}$ & $\begin{array}{c}\text { Interprestasi } \\
\text { Korelasi }\end{array}$ \\
\hline 0,754 & Tinggi \\
\hline
\end{tabular}

Berdasarkan hasil uji reliabilitas pada tabel 4 dan 5, maka dikatakan cukup 
diandalkan untuk mengukur kemampuan siswa.

\subsection{Teknik Pengumpulan Data}

Pengumpulan data dalam penelitian ini dilakukan dengan pemberian instrumen penelitian berupa tes menulis teks persuasi. Untuk tes kemampuan menulis teks persuasi (posttest) dilaksanakan pada pertemuan terakhir, kemudian tes tersebut dikerjakan oleh siswa masing-masing soal yang telah diberikan skor disesuaikan berdasarkan sistematika proses mengerjakannya, serta jenis aspek kemampuan menulis teks persuasi siswa yang diberikan dalam soal. Selanjutnya hasil pekerjaan siswa dikumpulkan oleh peneliti dengan dibantu oleh guru untuk diperiksa dan diberi skor.

\subsection{Teknik Analisis Data}

Data dalam penelitian ini akan dianalisis dengan menggunakan dua teknik analisis, yaitu analisis deskriptif dan analisis inferensial.

\subsubsection{Analisis Deskriptif}

Analisis deskriptif data penelitian berupa skor rata-rata, median, standar deviasi, varians, nilai maksimum, dan nilai minimum. Untuk keperluan analisis deskriptif dalam penelitian ini menggunakan bantuan SPSS versi 16. Analisis deskriptif juga dimaksudkan untuk mendeskripsikan kemampuan menulis teks persuasi siswa.

\subsubsection{Analisis Inferensial}

Analisis inferensial dimaksudkan untuk menguji hipotesis penelitian, yang dilakukan dengan uji normalitas dan uji homogenitas sebagai uji prasyarat untuk melakukan uji hipotesis penelitian dengan menggunakan uji-t.

\subsubsection{Uji Normalitas}

Uji normalitas data dimaksudkan untuk mengetahui apakah data yang diperoleh berasal dari populasi yang berdistribusi normal atau tidak. Untuk keperluan ini maka statistik yang akan digunakan adalah uji KolmogorovSmirnov dengan bantuan SPSS. Jadi, jika nilai sign $>0,05$ maka data berdistribusi normal, jika nilai sign $<0,05$ maka data tidak berdistribusi normal.

\subsubsection{Uji Homogenitas}

Uji homogenitas data dimaksudkan untuk mengetahui apakah varians data kedua tes yang diteliti mempunyai varians yang homogen atau tidak. Jadi, Jika nilai signifikansi $>\alpha=0,05$, maka varians kedua kelompok homogen dan jika nilai signifikansi $<\alpha=0,05$, maka varians kedua kelompok tidak homogen. Berdasarkan hasil uji homogenitas varians yang diperoleh nilai sig $=0,78$ hal ini berarti data yang diperoleh memiliki varians yang homogen.

\subsubsection{Uji Hipotesis dengan T-test}

Uji hipotesis dengan uji-t satu sampel data berpasangan (paired sample $t$ test) untuk mengetahui lebih lanjut pengaruh dari pemberian perlakuan model pembelajaran Pembelajaran Berbasis Masalah terhadap kemampuan menulis teks persuasi siswa, digunakan uji-t satu sampel data berpasangan.Dengan kriteria pengujian yaitu terima $\mathrm{H}_{0}$ jika $t_{\text {hitung }} \leq \mathrm{t}_{\text {tabel, }}$ dimana $t_{\text {tabel }}$ diperoleh dari daftar distribusi $t$ dengan $\mathrm{dk}=(\mathrm{n}-1)$ dan taraf kesalahan $\alpha=$ 0,05 . Untuk harga-harga $t$ lainnya $\mathrm{H}_{0}$ ditolak.Pada penelitian ini hipotesis yang diajukan adalah:

$\begin{aligned} \mathrm{H}_{0}= & \text { tidak terdapat pengaruh yang } \\ & \text { signifikan model pembelajaran } \\ & \text { berbasis masalah terhadap } \\ & \text { kemampuan menulis teks persuasi } \\ & \text { siswa. } \\ \mathrm{H}_{1}= & \text { terdapat pengaruh yang signifikan } \\ & \text { model pembelajaran berbasis } \\ & \text { masalah terhadap kemampuan } \\ & \text { menulis teks persuasi siswa. }\end{aligned}$




\section{HASIL DAN PEMBAHASAN}

\subsection{Hasil Penelitian}

Analisis data merupakan bagian yang sangat penting dalam suatu penelitian. Analisis data kemampuan menulis teks persuasi siswa kelas VIII SMP Negeri 11 Konawe Selatan terkhusus kelas VIII-A dari pretest dan posttest dengan dianalisis dengan menggunakan dua analisis yaitu hasil analisis deskriptif dan hasil analisis inferensial dengan menggunakan bantuan aplikasi SPSS. Berikut ini adalah penjabaran mengenai hasil penelitian tersebut.

\subsubsection{Hasil Analisis Deskriptif}

Hasil penelitian berupa deskripsi data pre-test dan post-test sebagai berikut.

Tabel 6 Hasil Pre-test dan Posttest

\begin{tabular}{|c|c|c|c|c|c|}
\hline \multirow{2}{*}{$\begin{array}{c}\text { Renta } \\
\text { Nilai }\end{array}$} & \multirow{2}{*}{$\begin{array}{c}\text { Tingkat } \\
\text { Pengua } \\
\text { saan } \\
\text { Siswa }\end{array}$} & $\begin{array}{c}\text { Fre } \\
\text { kue } \\
\text { nsi }\end{array}$ & $\begin{array}{c}\text { Present } \\
\text { ase (\%) }\end{array}$ & $\begin{array}{c}\text { Freku } \\
\text { ensi }\end{array}$ & $\begin{array}{c}\text { Presenta } \\
\text { se (\%) }\end{array}$ \\
\hline $\begin{array}{c}90<10 \\
0\end{array}$ & $\begin{array}{c}\text { Sangat } \\
\text { Tinggi }\end{array}$ & 0 & 0 & 7 & $24,13 \%$ \\
\hline $70<90$ & Tinggi & 4 & $\begin{array}{c}13,79 \\
\%\end{array}$ & 19 & $65,51 \%$ \\
\hline $40<70$ & Cukup & 23 & $\begin{array}{c}79,31 \\
\%\end{array}$ & 3 & $10,34 \%$ \\
\hline $20<40$ & Rendah & 2 & $6,89 \%$ & 0 & 0 \\
\hline $0<20$ & $\begin{array}{c}\text { Sangat } \\
\text { Rendah }\end{array}$ & 0 & 0 & 0 & 0 \\
\hline Jumla & & 29 & 100 & 29 & 100 \\
\hline
\end{tabular}

Berdasarkan data pada tabel 6, ditemukan perolehan skor keseluruhan berdasarkan tes (pretest) sebelum diberikan model pembelajaran berbasis masalah dan tes (postest) untuk melihat pengaruh model pembelajaran berbasis masalah terhadap kemampuan menulis teks persuasi siswa kelas VIII-A SMP Negeri 11 Konawe Selatan. Berdasarkan hasil analisis deskriptif pretest dapat diperoleh informasi bahwa diantara 29 orang siswa yang dijadikan sampel terdapat 4 orang siswa $(13,79 \%)$ mampu dalam menulis teks persuasi dan 25 orang siswa $(86,20 \%)$ tidak mampu dalam menulis teks persuasi.

Sedangkan untuk hasil analisis posttest dapat diperoleh informasi bahwa diantara 29 orang siswa yang dijadikan sampel terdapat 26 orang siswa $(89,65 \%)$ mampu dalam menulis teks persuasi dan 3 orang siswa $(10,34 \%)$ tidak mampu dalam menulis teks persuasi. Dengan demikian pengaruh model pembelajaran berbasis masalah terhadap kemampuan menulis teks persuasi siswa kelas VIII-A SMP Negeri 11 Konawe Selatan dikategorikan mampu secara klasikal. Dikatakan mampu karena jumlah persentase kemampuan secara klasikal yang diperoleh siswa adalah $89,65 \%$ dan sudah mencapai persentase kemampuan minimal klasikal yang telah ditetapkan yaitu $85 \%$.

\subsubsection{Hasil Analisis Inferensial}

Analisis yang digunakan dalam penelitian ini adalah uji hipotesis dengan uji-t. Melalui analisis inferensial, kita dapat mengetahui apakah hipotesisi dalam penelitian ini diterima atau ditolak. Terdapat beberapa tahap analisis yang menjadi prasyarat untuk melakukan analisis uji hipotesis yaitu analisis uji normalitas data dan analisis uji homogenitas data.

\subsubsection{Analisis Uji Normalitas}

Uji normalitas bertujuan untuk menguji apakah data variabel yang akan diteliti mempunyai distribusi normal atau tidak.Untuk menguji apakah data berdistribusi normal atau tidak digunakan statistik uji One Sample Kolmogorov Smirnov Test dengan menggunakan bantuan aplikasi SPSS Statistics 16. Dasar keputusan adalah jika nilai probabilitas statistik $>$ Level of Significant $=0,05$, maka model regresi memenuhi asumsi normalitas.

Untuk melihat apakah data berdistribusi normal atau tidak, dapat dilihat bahwa nilai Asymp. Sig. (2-tailed) untuk pretest adalah $0,086>\alpha$ (dengan $\alpha=$ 0,05), sehingga $\mathrm{H}_{0}$ diterima. Karena $\mathrm{H}_{0}$ diterima maka dapat disimpulkan bahwa sampel berasal dari populasi yang berdistribusi normal, yakni data tentang 
kemampuan menulis teks persuasi untuk pretest berdistribusi normal. Kemudian untuk postest terlihat bahwa nilai Asymp. Sig. (2-tailed) adalah $0,458>\alpha$ (dengan $\alpha$ $=0,05)$, sehingga $\mathrm{H}_{0}$ diterima.

Tabel Hasil Uji Normalitas

\begin{tabular}{|c|c|c|}
\hline Variabel & Sig & Keterangan \\
\hline Pre-test & 0,086 & Normal \\
\hline Post-test & 0,458 & Normal \\
\hline
\end{tabular}

Berdasarkan hasil uji pada tabel 7 karena $\mathrm{H}_{0}$ diterima maka dapat disimpulkan bahwa dari populasi yang berdistribusi normal, yakni data kemampuan menulis teks persuasi untuk Posttest berdistribusi normal.

\subsubsection{Analisis Uji Homogenitas}

Uji homogenitas digunakan untuk mengetahui apakah varian dari kedua tes pretest dan postest kemampuan menulis teks persuasi siswa homogen atau tidak. Berdasarkan hasil analisis uji homogenitas varians diperoleh nilai sig $=0,78$ karena nilai sig $=0,78>0,05=\alpha$ maka $\mathrm{H}_{0}$ diterima.

Tabel Hasil Uji Homogenitas

\begin{tabular}{|c|c|}
\hline Sig & Keputusan \\
\hline 0,78 & Terima $\mathrm{H}_{0}$ \\
\hline
\end{tabular}

Berdasarkan hasil uji homogenitas maka $\mathrm{H}_{0}$ diterima, hal ini berarti bahwa data yang diperoleh memiliki varians yang homogen.

\subsubsection{Pengaruh Model Pembelajaran Berbasis Masalahterhadap Tingkat Kemampuan Menulis Teks Persuasi}

Pengujian kemampuan responden yang telah mendapatkan perlakuan berupa pemberian model pembelajaran berbasis masalah akan memiliki skor rata-rata lebih tinggi dibandingkan pengetahuan responden sebelum diberikan perlakuan model pembelajaran berbasis masalah hasil analisis statistik menggunakan uji paired $t$ tes.

Berdasarkan hasil analisis menunjukkan bahwa pada tahap posttest dan pretest perbedaan rata-rata nilai sebesar 7,79 Sample t-test diperoleh signifikansi 0,000 kurang dari taraf signifikan $(\alpha)=0,05$, maka $\mathrm{H}_{0}$ ditolak. Artinya $\mathrm{H}_{1}$ diterima karena ada pengaruh yang signifikan antara rata-rata nilai sebelum perlakuan dengan rata-rata nilai sesudah perlakuan. Hasil statistik menunjukkan bahwa $t_{\text {hit }}=8,814>\mathrm{t}_{\text {tabel }}=$ 2,045 dan $p=0,000$, atau $p$ value $<0,05$ artinya pada tahapan ini ada perbedaan sebelum dan sesudah pemberian model pembelajaran berbasis masalah. Sehingga dapat disimpulkan bahwa model pembelajaran berbasis masalah berpengaruh terhadap kemampuan menulis teks persuasi siswa kelas VIII-A SMP Negeri 11 Konawe Selatan, karena dapat memberikan peningkatkan pengetahuan siswa dari pre-test ke post-test.

\subsection{Pembahasan}

Faktor mendasar yang menyebabkan sulitnya meningkatkan kemampuan menulis teks persuasi siswa kelas VIII SMP Negeri 11 Konawe Selatan khususnya kelas VIII-A adalah (1) proses pembelajaran masih berpusat pada guru; (2) Sistem pembelajarannya selama ini masih mononton; (3) Pada proses pembelajarannya siswa dituntut untuk menyelesaikan soal-soal yang diberikan tanpa diajarkan strategi yang bervariasi untuk menemukan jawaban soal dengan mudah diingat. Oleh karena itu, guru perlu memperbaiki pembelajaran bahasa indonesia dengan mencoba menggunakan sebuah model pembelajaran berbasis masalah.

Model tersebut diharapkan dapat memberikan perubahan kepada siswa agar dalam proses pembelajaran siswa tidak hanya berpusat pada guru saja melainkan berpusat pada siswa, siswa dapat dengan mudah dalam memahami materi pembelajaran bahasa indonesia yang dikaitkan dengan lingkungan dan teman kelompok, selain itu dengan adanya model pembelajaran ini diharapkan dapat berpengaruh dalam memberikan 
peningkatan kepada siswa dalam menulis khususnya teks persuasi.

\subsubsection{DeskripsiPelaksanaan Pembelajaran}

Selama proses penelitian berlangsung peneliti kelas VIII-A yang digunakan sebagai sampel penelitian yakni guru membuka pelajaran dan menginformasikan topik pembelajaran yang akan dibahas, pemberian apersepsi dan motivasi kepada peserta didik antusias dalam belajar di kelas. Tahap selanjutnya guru menjelaskan tujuan pembelajaran kepada peserta didik, diteruskan guru menjelaskan mekanisme pelaksanaan pengalaman belajar sesuai dengan langkah-langkah pembelajaran, dan guru mengarahkan siswa untuk membentuk kelompok secara heterogen. Kemudian pada tahap mengamati guru meminta siswa dalam kelompoknya masing-masing mengamati LKPD yang dibagikan untuk didiskusikan dan diselesaikan secara berkelompok. Pada penelitian ini menggunakan LKPD tujuannya untuk membantu siswa menemukan masalahanmasalah yang sering diperoleh atau yang disajikan dalam LKPD. Dalam pelaksanaannya LKPD didesain agar siswa mampu menemukan sebuah masalah yang dipelajari dengan berbagai pengalaman sendiri khususnya dilingkungan sekitar. Akan tetapi, dalam pelaksanaan pembelajaran dengan menggunakan LKPD ini ada beberapa siswa yang mampu menemukan masalah dan dapat menyelesaikan masalah tersebut. Namun, sebaliknya masih banyak siswa yang belum mampu memahami materi yang diberikan sehingga masih kesulitan dalam menemukan sebuah masalah dan kesulitan dalam menyelesaikannya.

Untuk itu, pada tahap membimbing individu atau kelompok guru berperan memberi pengarahan dan bimbingan kepada peserta didik melalui penjelasan atau pertanyaan yang mengarah kepada peserta didik melalui penjelasan atau pertanyaan yang mengarah kepada penyelesaikan masalah. Setelah semua kelompok mengerjakan LKPD sesuai waktu yang ditetapkan, pada tahap menyajikan hasil karya, beberapa peserta didik dipilih untuk mewakili kelompoknya untuk mempresentasikan hasil kerja kelompoknya dan ditanggapi oleh kelompok lain. Guru berperan memandu jalannya diskusi, meluruskan jika jawaban keliru dan membantu peserta didik dalam mengambil kesimpulan jawaban yang benar. Diakhir pembelajaran, guru mengajak peserta didik untuk melakukan refleksi terhadap pembelajaran yang dilakukan dan terakhir guru memberi tugas untuk dikerjakan di rumah secara individu.

Ditinjau dari aktifitas guru, tingkat keberhasilan keterlaksanaan proses pembelajaran selama enam kali pertemuan dengan empat kali pertemuan yang digunakan untuk proses pembelajaran dan dua kali pertemuan digunakan untuk pelaksanaan pre-test dan post-test kemampuan menulis teks persuasi siswa. Pada pertemuan pertama dan kedua, guru dalam hal ini peneliti masih melakukan proses penyesuaian tahap-tahap pembelajaran model pembelajaran berbasis masalah dalam kelas, begitu pula peserta didik masih melakukan penyesuaian dengan model tersebut. Selain itu, peneliti juga masih menyesuaikan kemampuan peserta didik dalam kelas dan menyelesaikan masalah, serta berapa banyak durasi waktu yang digunakan peserta didik secara berkelompok untuk menyelesaikan soal yang diberikan. Pada saat proses pembelajaran pertemuan pertama, guru memberikan soal latihan kepada masing-masing kelompok dalam LKPD. Ternyata masing-masing kelompok membutuhkan waktu yang cukup lama dalam menyelesaikan soal tersebut, sehingga hal ini memakan waktu yang lama dalam diskusi kelompok. Akibatnya, terdapat kegiatan-kegiatan pada pertemuan pertama yang telah direncanakan dalam RPP tidak terlaksana. Pada pertemuan ketiga hingga seterusnya, dalam memberikan soal LKPD kepada masing- 
masing kelompok cukup diberikan satu nomor sajasehingga siswa memiliki waktu lebih banyak saling bertukar pendapat antar kelompok maupun kelompok lain hingga selesai.

\subsubsection{Kemampuan Menulis Teks Persuasi Siswa Sebelum dan Sesudah diajar dengan Model Pembelajaran Berbasis Masalah}

Data kemampuan menulis teks persuasi siswa diperoleh melalui tes menulis teks persuasi. Sebelum diberikan perlakuan yaitu berupa model pembelajaran berbasis masalah, tes yang diberikan kepada siswa yaitu menulis teks persuasi dengan jenis teks persuasi yang telah ditentukan. Tujuannya agar peneliti mengetahui tingkat kemampuan awal siswa sebelum diberikan perlakuan dan setelah diberikan perlakuan, apakah dengan model pembelajaran berbasis masalah dapat memeberikan pengaruh dalam menulis teks persuasi siswa.

Pengujian hipotesis dalam penelitian ini menggunakan uji-t data berpasangan. Berdasarkan hasil uji hipotesis dengan menggunakan uji-t data berpasangan diperoleh nilai thitung $8,814>\mathrm{t}_{\text {tabel }}=$ 2,045 dan $p=0,000$, atau $p$ value $<0,05$ sehingga $\mathrm{H}_{0}$ ditolak dengan demikian kita dapat menarik suatu kesimpulan bahwa terdapat pengaruh yang signifikasi dengan menggunakan model pembelajaran berbasis masalah terhadap kemampuan menulis teks persuasi siswa kelas VIII-A SMP Negeri 11 Konawe Selatan dengan taraf kepercayaan 95\%. Dengan demikian terdapat peningkatan kemampuan menulis teks persuasi siswa. Dimana model pembelajaran tersebut menuntut peran aktif siswa dan mendorong siswa untuk dapat mengembangkan kemampuan dalam komunikasi antar anggota kelompok sehingga dapat lebih mudah memecahkan masalah dan belajar menulis teks persuasi yang diberikan dengan baik.

\section{PENUTUP}

\subsection{Kesimpulan}

Berdasarkan hasil penelitian dan analisis data yang dilakukan, pada penelitian ini sebelum menguji t-test terlebih dahulu dengan menguji normalitas, homogenitas. Hal ini membuktikan bahwa nilai Asymp. Sig. (2tailed) untuk pretest adalah 0,086 > $>$ (dengan $\alpha=0,05$ ), sehingga sampel berasal dari populasi yang berdistribusi normal dan uji homogenitas varians diperoleh nilai sig $=0,78$ karena nilai $\operatorname{sig}=$ $0,78>0,05$ berarti data yang diperoleh memiliki varians yang homogen. Kemudian uji t-test yaitu hasil analisis pada tahap posttest dan pretest perbedaan rata-rata nilai sebesar 7,79 Sample t-test diperoleh signifikansi 0,000 kurang dari taraf signifikan $(\alpha)=0,05$, maka $\mathrm{H}_{0}$ ditolak. Artinya $\mathrm{H}_{1}$ diterima dan hasil statistik menunjukkan bahwa $t_{\text {hit }}=8,814>$ $\mathrm{t}_{\text {tabel }}=2,045$ dan $p=0,000$, atau $p$ value $<0,05$ artinya pada tahapan ini ada perbedaan sebelum dan sesudah pemberian model pembelajaran berbasis masalah terhadap kemampuan menulis teks persuasi siswa kelas VIII-A SMP Negeri 11 Konawe Selatan.

Hal ini dapat dilihat juga dari presentase hasil pretest yaitu dari 29 siswa yang mengikuti tes secara individu terdapat 4 siswa atau $13,79 \%$ masuk kategori mampu dan 25 siswa atau 86,20\% yang masuk kategori tidak mampu. Sedangkan pada posttest mengalami perubahan atau peningkatan yaitu dengan presentase $89,65 \%$ atau sebanyak 26 siswa masuk kategori mampu dan 3 siswa atau 10,34\% dikatakan tidak mampu, sehingga pada penelitian ini pembelajaran menggunakan model pembelajaran berbasis masalahdapat memberikan pengaruh terhadap kemampuan menulis teks persuasi siswa kelas VIII-A SMP Negeri 11 Konawe Selatan karena indikator keberhasilan penelitian telah tercapai yaitu $85 \%$. 


\subsection{Saran}

Berdasarkan hasil penelitian ini, maka penulis mengemukakan saran-saran sebagai berikut.

1. Guru dapat menerapkan model pembelajaran berbasis masalah sebagai salah satu model pembelajaran yang efektif dalam pembelajaran.

2. Bagi guru yang akan menggunakan model pembelajaran berbasis masalahini, maka perlu memperhatikan berbagai hal seperti, (1) selalu memberikan motivasi siswa agar siswa selalu termotivasi, sehingga dapat menumbuhkan semangat yang baru, (2) ketika terdapat siswa dalam kelompok kurang aktif maka guru mendorong tiap kelompok agar semua aktif dengan tidak melihat benar salah melainkan saling bekerja sama mengeluarkan pendapat, (3) guru dalam memberikan bantuan kepada siswa ketika kesulitan yang benar-benar dialami oleh siswa dan dilakukan secara adil.

\section{DAFTAR PUSTAKA}

Ana, Haerun. 2011. Perspektif

Pembelajaran Bahasa Indonesia.

Kendari: FKIP Unhalu.

Afisha. 2015. Pengaruh Model Problem

Based Learning Terhadap

Kemampuan Argumen dan Hasil

Belajar Peserta Didik di Kelas VII

SMP Negeri 20

Bandar Lampung.http://jurnal.fkip.

unila.ac.id.(Diakses hari kamis 27

Desember).

Asyiqin, dkk. 2018. Pengaruh Model

Problem Based Learning (PBL)

Terhadap Keterampilan Menulis

Teks Eksposisi. http://e-

jurnal.unp.ac.id. (Diakses hari

kamis 27 Desember).

Arikunto, Suharsini. 2013. Prosedur Penelitian. Jakarta: Rineka Cipta.

Dalman. 2016. Keterampilan Menulis. Jakarta: PT. Raja Grafindo Persada

Finoza, Lamuddin. 1993. Komposisi Bahasa Indonesia. Jakarta: Diksi Insan Mulia.
Hakim A, dkk. 1993. Segi Praktis Bahasa Indonesia. Jakarta: JC layanan terbaik Menuju Prestasi.

Jihad, Asep dan Haris, Abdul. 2012. Evaluasi Pembelajaran. Multi Presindo:Yogyakarta.

Keraf, Gorys.1995. Eksposisi (Komposisi Lanjutan II). Jakarta: Penerbit PT. Grasindo.

Kosasih. 2017. Bahasa Indonesia. Klaten: Intan Pariwara.

Komalasari, Kokom. 2015. Pembelajaran Kontekstual (Konsep dan Aplikasi). Bandung: PT Refika Aditama.

Mariani, Ani. 2010. Guru Bahasa Indonesia Harus Bisa Menulis. Jakarta: Pusat Bahasa.

Mahsun. 2014. Teks dalam Pembelajaran Bahasa Indonesia (Kurikulum 2013). Jakarta: Rajawali Pers.

Nuraini, Fivi. 2017. Penggunaan Model Problem Based Learning (PBL) Untuk Meningkatkan Hasil Belajar IPA Siswa Kelas 5 SD.http://ejurnalmitrapendidikan.com. (Diakses hari kamis 27 Desember)

Rosidi, Imron. 2009. Menulis Siapa Takut?. Yogyakarta: Penerbit Kanisius.

Rusman. 2010. Model-Model Pembelajaran (Mengembangkan Profesionalisme Guru). Bandung: Mulia Mandiri Pers.

Sudjana. 2005. Metode Statistik. Bandung: Tarsito.

Soebachman, Agustina. 2016. Mahir Menulis dalam 4 Hari. Yogyakarta: Kauna Pustaka.

Syah, Muhibbin. 2014. Psikologi Pendidikan. Bandung: Rosda.

Sumardjo, Jakob. 2014. Catatan Kecil Tentang Menulis Cerpen. Jakarta: Rajawali Pers.

Sugiyono. Metode Penelitian Pendidikan (Pendekatan Kuantitatif, Kualitatif, dan $R \& D$ ). Bandung: Alfabeta.

Tarigan, Henry Guntur. 2013. Menulis (Sebagai Suatu Keterampilan Berbahasa). Bandung: Angkasa. 